\begin{tabular}{lc}
\hline & ANNALES \\
& UNIVERSITATIS MARIAE CURIE-SKŁODOWSKA \\
LOL. V & SECTIO N \\
\hline
\end{tabular}

ISSN: 2451-0491 • e-ISSN: 2543-9340 • CC-BY 4.0 • DOI: 10.17951/en.2020.5.45-68

\title{
Dziesięć obligacji polonistycznej dydaktyki XXI wieku
}

\section{Ten Bonds of Polish Language and Literature Teaching in the $21^{\text {st }}$ Century}

\author{
Anna Ślósarz \\ Uniwersytet Pedagogiczny im. Komisji Edukacji Narodowej w Krakowie. \\ Instytut Filologii Polskiej \\ ul. Podchorążych 2, 30-084 Kraków, Polska \\ anna.slosarz@up.krakow.pl \\ https://orcid.org/0000-0001-5524-3227
}

\begin{abstract}
The $21^{\text {st }}$-century didactics of Polish language and literature can meet social obligations on ten levels. For the examination of their completion, formal documents were analyzed: basic curricula, textbooks, written class assignments, methodical publications, conference information, and web portals. Interviews and survey were conducted. It turned out that the $21^{\text {st }}$-century didactics of Polish language and literature does not meet social obligations. It is necessary to update the objectives, strategies, methods, content and means of teaching, to eliminate unauthorized interpretations and to cooperate with the perieducational environments.
\end{abstract}

Keywords: social obligations; basic curricula; textbooks; methodical publications; strategies; methods; goals

Abstrakt. Polonistyczna dydaktyka w XXI wieku może spełniać społeczne zobowiązania na dziesięciu płaszczyznach. Dla sprawdzenia ich realizacji przeanalizowano dokumenty formalne zastane: podstawy programowe, programy kształcenia, podręczniki, publikacje metodyczne, informacje konferencyjne i portale internetowe. Przeprowadzono zadania klasowe, wywiady i ankietę. Okazało się, że polonistyczna dydaktyka XXI wieku nie spełnia społecznych zobowiązań. 
Trzeba zaktualizować jej cele, strategie, metody i środki kształcenia, eliminować nieuprawnione interpretacje, współpracować ze środowiskami okołoedukacyjnymi.

Słowa kluczowe: społeczne zobowiązania; podstawy programowe; podręczniki; publikacje metodyczne; strategie; metody; cele

\section{WPROWADZENIE}

Tytuł z homonimem obligacje definiuje społeczno-kulturowy potencjał polonistycznej dydaktyki wynikający z jej zobowiązań wobec państwa i reprezentowanego przez rząd społeczeństwa. W dodatku obligacje (skarbowe) to emitowane przez rząd papiery wartościowe, które pomnażają powierzony mu kapitał o odsetki. Obligacje sprawiają zatem, że i posiadacz (dydaktyka), i państwo zyskują środki na rozwój.

Dydaktyka polonistyczna obejmuje literaturoznawstwo, językoznawstwo i nauki o sztuce, a ponadto jest powiązana z naukami społecznymi: wiedzą o komunikowaniu społecznym i mediach oraz pedagogiką. Nieodłączne od kształcenia wychowanie jest nie tylko wprowadzaniem ucznia w świat kultury i rozwijaniem zdolności, lecz przede wszystkim rozwijaniem kompetencji społecznych (Morbitzer 2014: 123). Dydaktyka języka ojczystego rozwija potencjał integracyjny społeczeństw, istotny dla zbiorowości w obliczu m.in. konieczności zjednoczenia (np. odrodzonego państwa polskiego po 1918 roku), problemu imigracyjnego (Australia, Europa) czy dążeń separatystycznych regionów (Hong-Kong, Katalonia, Irlandia, Szkocja itd.).

\section{CEL I SPOSÓB ANALIZY ORAZ MATERIAŁ BADAWCZY}

Cele badania to: 1) zestawienie dziesięciu cech definicyjnych każdej dydaktyki przedmiotowej (z uwzględnieniem polskich realiów), czyli płaszczyzn, na których polonistyczna dydaktyka XXI wieku może spełniać społeczne zobowiązania; 2) próba oceny, w jakim stopniu polonistyczna dydaktyka je spełnia.

Przeprowadzono jakościową analizę dokumentów formalnych, zastanych, pochodzących z XX i XXI wieku:

1) centralnych programów nauczania,

2) podstaw programowych i ministerialnych rozporządzeń (Chrząstowska red. 1990; Podstawa programowa $z$ komentarzami 2009; rozporządzenie Ministra Edukacji Narodowej z dnia 21 maja 2001 roku w sprawie ramowych planów nauczania w szkołach publicznych; rozporządzenie Ministra Edukacji Narodowej i Sportu z dnia 26 lutego 2002 roku w sprawie podstawy 
programowej wychowania przedszkolnego oraz kształcenia ogólnego w poszczególnych typach szkół; rozporządzenie Ministra Edukacji Narodowej z dnia 30 listopada 2006 roku zmieniające rozporządzenie w sprawie podstawy programowej wychowania przedszkolnego oraz kształcenia ogólnego w poszczególnych typach szkół; rozporządzenie Ministra Edukacji Narodowej z dnia 3 lipca 2007 roku zmieniające rozporządzenie w sprawie podstawy programowej wychowania przedszkolnego oraz kształcenia ogólnego w poszczególnych typach szkół; rozporządzenie Rady Ministrów z dnia 24 lipca 2007 roku uchylające rozporządzenie Ministra Edukacji Narodowej zmieniające rozporządzenie w sprawie podstawy programowej wychowania przedszkolnego oraz kształcenia ogólnego w poszczególnych typach szkół; rozporządzenie Ministra Edukacji Narodowej z dnia 23 sierpnia 2007 roku zmieniające rozporządzenie w sprawie podstawy programowej wychowania przedszkolnego oraz kształcenia ogólnego w poszczególnych typach szkół; rozporządzenie Ministra Edukacji Narodowej z dnia 29 sierpnia 2008 roku zmieniające rozporządzenie w sprawie podstawy programowej wychowania przedszkolnego oraz kształcenia ogólnego w poszczególnych typach szkół),

3) wybranych podręczników (Adamczyk, Chrząstowska i Pokrzywniak 1987; Antosik 1999; Balicki i Makowski 1943; Biała i Krawczyk 2002; Biedrzycki, Jaskółowa i Nowak 2012; Brożek 2011; Chmiel 2009; Chmiel i Równy 2019; Chrząstowska 2002; Chrząstowska red. 2002; Drabik-Frączek, Pstrąg i Zawadzki 2007; Dyduch, Kłakówna i Jędrychowska 1994; Garsztka, Olszowska i Dziuba 1999; Lotterhoff, Sucharska, Kuchta, Wojciechowska i Zabrodzka red. 2019; Łuczak, Prylińska i Maszka 2002; Niemczyńska i Friedmann 2002; Rosiek, Maćkiewicz i Majchrowski 2002; Szulc i Gorzałczyńska-Mróz 2010; Wóycicki 1920-1921),

4) materiałów konferencyjnych (materiały z IV Kongresu Dydaktyki Polonistycznej),

5) stu zadań uczniowskich ${ }^{1}$,

6) publikacji zamieszczonych w Internecie i portali internetowych wykorzystywanych w celach edukacyjnych (Pasterski 2017; witryny: Kulturalna Polska, Klasyka Literatury. Ostatni dzwonek, Ściąga).

Dokumenty formalne zastane potraktowano jako wynik społecznego konsensusu, ponieważ ich autorzy są reprezentantami środowisk, zebrali i przetworzyli dane, a wytworzone przez nich teksty zostały zarchiwizowane i udostępnione. Posłużyły one do scharakteryzowania edukacji polonistycznej w skali makro.

1 Były to wypracowania na temat Lalki, napisane w roku szkolnym 2018/19 w czterech klasach prowadzonych przez trzy nauczycielki w trzech różnych szkołach. 
Natomiast dokumenty nieformalne, w postaci dwudziestu nieustrukturyzowanych wywiadów ${ }^{2}$ oraz ankiet wypełnionych przez 31 uczniów $^{3}$, wykorzystano do wyjaśnienia zachodzących procesów (Łuczewski i Bednarz-Łuczewska 2012: 184), ujawniając potrzeby w skali mikro.

W celu podwyższenia rzetelności badania oraz triangulacji metod porównano dokumenty formalne i nieformalne, oddzielając $w$ ten sposób oficjalne deklaracje od rzeczywistych doświadczeń uczestników procesu edukacyjnego.

Odniesiono się do dziesięciu obligacji polonistycznej dydaktyki, które pilnie wymagają od środowiska uniwersyteckiego rozwinięcia i dopracowania jako wynikłe z przemian cywilizacyjnych oraz narosłe w rezultacie wieloletnich zaniedbań. Pominięto natomiast kwestie wynikające ze sposobu kształcenia, takie jak: kryteria oceniania, zagadnienia niepowodzeń szkolnych itp.

\section{OBLIGACJE POLONISTYCZNEJ DYDAKTYKI XXI WIEKU}

\section{Aktualizacja celów kształcenia}

Aktualizacja celów kształcenia należy do nauczycieli i dydaktyków, rodziców, dyrektorów, pedagogów, psychologów, przedstawicieli nauczycielskich stowarzyszeń itd. W okresie PRL programy nauczania były centralne, jednolite dla wszystkich uczniów poszczególnych typów szkół. Dopiero w latach 1990 i 1995 Bożena Chrząstowska (red. 1990, 1995) wraz z zespołem opracowała autorskie programy nauczania. Dwa równoległe programy z 1990 roku nastawione były na realizację tych samych celów, choć za pomocą nieco innych treści. Kolejne podstawy programowe opracowywane były w Polsce przez kilku dydaktyków pod patronatem Ministerstwa Edukacji Narodowej i z pominięciem pozostałych środowisk.

Podstawy programowe zmieniały się wraz z rządami, co nie posłużyło trwałości i wiarygodności ani jednych, ani drugich. Wciąż istnieje potrzeba aktualizowania celów kształcenia i przystosowywania ich nie tylko do obecnego stanu wiedzy i poziomu rozwoju, lecz także do społecznych potrzeb.

Wspólne podejmowanie decyzji co do celów kształcenia zwiększa poczucie odpowiedzialności za jego rezultaty. W Australii treści kształcenia ustalane są na poziomie administracji stanów, w Niemczech planują je landy, w Czechach

2 W latach 2015-2019 przeprowadzono 10 wywiadów z uczniami oraz 10 wywiadów z nauczycielami szkolnymi, pracownikami oświaty i dydaktykami akademickimi z Czudca, Krakowa, Łomży, Myślenic, Opola, Szczecina, Świątnik Górnych, Warszawy, Wrocławia, Zakliczyna n. Dunajcem.

3 Ankieta została przeprowadzona w publicznym Technikum Hotelarskim 12 października 2018 roku. Jej wyniki znajdują się w archiwum autorki. 
zaś szkoły, ale w każdym z tych krajów cele kształcenia uzgadniane są centralnie. W Polsce i cele, i treści kształcenia ustalane są centralnie, lecz obecne natężenie sporu politycznego utrudnia ich uzgodnienie. Pozostają więc bardzo ogólne, a przez to są rozmaicie interpretowane.

Brak zaangażowania środowisk akademickich w formułowanie celów kształcenia i zakresu materiału nauczania idzie w parze z kontestowaniem kolejnych propozycji ministerialnych. W efekcie dydaktyka polonistyczna wymyka się spod społecznej kontroli, gdyż nauczyciele układają autorskie programy. Tym samym na lekcje polskiego mogą wkraczać treści antypolskie czy rasistowskie, różne hierarchie wartości i opinie mogą być narzucane metodą agenda setting lub przez media społecznościowe $e^{4}$ W takich warunkach edukacja patriotyczna (Kania 2015) i obywatelska (Koc 2018a) stała się trudna do realizacji, dlatego bywa pomijana (Kania 2016:54-53), a zadania polonistycznej dydaktyki niejednokrotnie są lekceważone.

\section{Opracowanie strategii kształcenia}

Strategie nauczania języka polskiego wywodzą się z dydaktyki ogólnej i nie zostały zaktualizowane od dziesięcioleci, choć zmienił się zarówno kształt literackiego tekstu, jak i praktyki czytania, włączające nawigowanie po Internecie. Uczniowie z upodobaniem czytają zachodnie cykle powieściowe (Zasacka 2015: 35-50), a polską klasykę literacką poznają często ze streszczeń (wywiad z uczniami $2,3,5$ ), ponieważ na egzaminie maturalnym sprawdzane są ujednolicone i stabilne interpretacje lektur. Tymczasem współcześni literaturoznawcy dowodzą, że „tekst nie ma stałego, niezmiennego znaczenia - które tworzy się dopiero w procesie lekturowej reakcji czytelnika" (por. Fish 1980: 306; Nycz 2000: 115-116).

Konieczne jest zaktualizowanie teorii dydaktycznej (Koc 2018b: 71-83) oraz wdrożenie takiej strategii kształcenia i zasad egzaminowania, które pozwolą uczniom na samodzielne rozumienie tekstów w granicach prawomocności interpretacji (por. Eco, Rorty, Culler, Brooke-Rose i Collini eds. 2008; Markiewicz 1996: 59-74)5. Tymczasem w praktyce na lekcjach polskiego wciąż

4 Jak np. obwinianie Polaków za Holocaust czy ludzkości za skutki globalnego ocieplenia, podczas gdy związek ocieplenia klimatu i działalności człowieka nie został udowodniony (zob. Marohasy ed. 2017).

5 Nauczyciele i zewnętrzni egzaminatorzy potrafią uszanować rozmaite interpretacje wtedy, gdy umieją ocenić ich prawomocność. Pomaga im znajomość współczesnych teorii literatury. Egzamin może być rzetelny mimo przedstawienia przez zdających rozmaitych - lecz prawomocnych - interpretacji. 
dominuje strategia odwołująca się do psychologii asocjacyjnej (por. Okoń 1987: 347): lektury mają być przeczytane i poznane poza szkołą, a ich obowiązujące interpretacje - przedstawione w szkole i powiązane z innymi wiadomościami. Uczniowskie odczytania tracą znaczenie, gdy na egzaminach sprawdzana jest obowiązująca interpretacja. Brakuje czasu na stosowanie strategii problemowej, a tym bardziej emocjonalnej i operacyjnej. Dyskusja bywa rozumiana jako ryzyko w obliczu kryteriów egzaminacyjnych pojmowanych jako żądające historycznie i instytucjonalnie utrwalonej interpretacji, której nauczyciele szukają w wystandaryzowanych materiałach edukacyjnych, udostępnianych przez biblioteki i wydawnictwa. Rezygnuje się z uwzględniania interpretacji uczniowskich oraz z wywarzania interpretacyjnych wspólnot (por. Barton i Hamilton 2003; Barton, Hamilton i Ivanic eds. 2005; Peplow, Swann, Trimarco i Whiteley 2016).

Dostępność internetowych streszczeń wpływa na interpretacje lektur. W przeprowadzonych wywiadach uczniowie przyznawali: „[...] gdy mam styczność z jakąś trudniejszą lekturą, bardziej złożoną, to czasami... żeby po prostu lepiej zrozumieć fragment albo całość utworu, czytam sobie konkretne analizy tekstów"6. Ponadto wywiady ujawniły, że uczniowie naśladują cudzy tok myślenia i wartościowania. Oznacza to, że interpretacjami polskiej klasyki literackiej sterują autorzy opracowań, podręczników i filmowych adaptacji oraz podmioty komercyjne, które prowadzą popularne portale, wykorzystywane w celach edukacyjnych ${ }^{7}$.

Sytuacji tej można zaradzić, wprowadzając np. strategię kształcenia w postaci multimedialnych modułów tematycznych, co uczyniono w Australii. Interpretacje kluczowych dla kultury narodowej tekstów dokonywane są tam w klasowych wspólnotach interpretacyjnych na drodze wspólnego, głośnego czytania, przeżywania i komentowania na lekcji, a następnie odnoszenia ich treści do współczesności i utrwalania wiedzy podczas wspólnego oglądania celowo dobranych multimediów na ten sam temat (zob. Modules 2017). Interpretacja ukierunkowana jest przez temat modułu (np. Belonging).

Okresowa wymiana kierunków interpretacji lektury (albo lektur) i tematów egzaminacyjnych (co 4-5 lat) sprawia w Australii, że internetowe porady interpretacyjne szybko stają się nieaktualne, a tworzenie nowych wymaga kompetencji i wysiłku, toteż wykorzystanie i tworzenie tego typu „pomocy” zostało utrudnione. Strategia współczytania (Wróblewski 2014: 194), aktualizowania

6 Cytaty pochodzą z wywiadów przeprowadzonych z uczniami klas drugich liceów ogólnokształcących w Krakowie i Łomży. Zapisy wywiadów znajdują się w archiwum autorki.

7 Na przykład portale Ściąga czy Kulturalna Polska bywają uważane za edukacyjne przez licealistów, a nawet przez studentów. 
(odnoszenia do współczesności), precyzowania i objaśniania interpretacji lektur multimediami służy formowaniu postaw wobec języka, kultury i państwa. Podobnie skuteczne strategie kształcenia wdrożono w Niemczech, Federacji Rosyjskiej, Japonii. Natomiast nie upowszechniono strategii kształcenia, specyficznej dla dydaktyki polonistycznej.

\section{Wypracowanie metod nauczania}

Metody nauczania, czyli celowo i systematycznie stosowane sposoby pracy, mają umożliwiać osiągnięcie celów kształcenia. Powinny zatem być adekwatne do przyzwyczajeń komunikacyjnych, umiejętności technicznych i potrzeb rozwojowych pokolenia, którego nazwy bywają odnoszone do sieci, gier, ekranów, myszki itp. (np. sieciaki, generation gamers, ekranolatki, urodzeni z myszka $w$ ręku), ponieważ komunikuje się i współpracuje w świecie wirtualnym. Kryzys czytelnictwa i dominacja kultury audiowizualnej mogą więc stać się punktem wyjścia do opracowania metod nauczania języka polskiego odwołujących się do konektywizmu.

Metody słowne (Okoń 1987: 271) są nieodpowiednie dla pokolenia sieci i gier, które woli wspólnie wytwarzać wiedzę niż ją percypować. Środowisko dydaktyki polonistycznej zaproponowało już metody dydaktyczne adekwatne do tego rodzaju potrzeb. W XX wieku były to analiza porównawcza (Chrząstowska 1988: 122-148; Chrząstowska 2009: 115-121) i przekład intersemiotyczny (w kształceniu językowym: Dyduchowa 1988; w kształceniu literackim: Uryga 1996), wynikłe z konieczności porównywania informacji. Natomiast w XXI wieku zaproponowano metody polegające na ukierunkowywaniu interpretacji przez selekcjonowanie informacji drogą skupiania uwagi na tych najważniejszych: drama online (Kulig-Kozłowska 2017: 101-128), questing (Bryzek 2016: 42-51), multimedialne moduły tematyczne (Ślósarz 2018), metoda wizualizacji tekstów (Poręba 2014b: 101-111; Wileczek i Jaros 2014: 123-133) oraz słów kluczowych wierszy (Ślósarz 2019: 207-241). Szkolni poloniści rzadko je znają, dlatego posługują się najczęściej metodami ogólnodydaktycznymi, czego dowodzi Polonistyczna dydaktyka ogólna (Fiszbak red. 2019).

\section{Przywracanie ciągłości rozwoju dydaktyki polonistycznej}

Społeczne obligacje dydaktyki polonistycznej rząd oprocentował bardzo wysoko np. w okresie międzywojennym, gdy nauczanie języka polskiego stało się fundamentalne dla integracji zjednoczonego państwa. Po II wojnie światowej imponujący dorobek dydaktyków międzywojnia został celowo wymazany, 
a społeczne aspekty kształcenia sprowadzono do zadań propagandowych. Zniechęciło to wielu nauczycieli i dydaktyków do rządowych obligacji, skutkując oderwanym od społecznych realiów strukturalizmem - wycofaniem się z życia publicznego i emigracją wewnętrzną. Skoncentrowano się na kształceniu w wymiarze estetycznym (np. Chrząstowska 1979). Natomiast po 1989 roku przypomniano i na nowo rozwinięto wypracowane w dwudziestoleciu międzywojennym koncepcje pomnożenia formacyjnych (np. Jazownik 2004; Jędrychowska 1996) obligacji przedmiotu język polski.

Dlatego należy docenić wysiłek przywrócenia dorobku międzywojennej dydaktyki polonistycznej, podjęty na Uniwersytecie Zielonogórskim. Dwutomowa antologia Teoria ksztatcenia literackiego w latach 1918-1939 (Jazownik red. 2001a, 2001b), a następnie Leszka Jazownika W kręgu historii i teorii edukacji polonistycznej (2011) przypomniały fundamentalne zasady patriotycznego kształcenia przez literaturę i język, wypracowane przed II wojną światową i procentujące w jej trakcie, a wcześniej - podczas wojny polsko-bolszewickiej i budowy odrodzonego państwa. Obligacje przedmiotu język polski zaowocowały aktualizującymi interpretacjami, np. walczący z niemieckim i sowieckim okupantem przyjmowali pseudonim „Kmicic”, jak por. Antoni Burzyński czy ppor. Wincenty Ciszek.

Warto dziś korzystać zarówno z imponującego dorobku dydaktyki polonistycznej okresu dwudziestolecia międzywojennego, jak i z osiągnięć wcześniejszych epok, w których język i literatura umożliwiły zachowanie tożsamości narodowej.

\section{Eliminacja antywiedzy i nieuprawnionych interpretacji}

Krzysztof Mudyń (1995: 99) słusznie stwierdził, że „jeśli posiadana reprezentacja poznawcza bardziej deformuje, niż reprezentuje odpowiedni aspekt rzeczywistości, to zasługuje na miano antywiedzy". Fałszywe reprezentacje powielała i produkowała PRL-owska propaganda, wywierając wpływ na interpretacje wielu lektur, zwłaszcza o odniesieniach patriotycznych, społecznych i religijnych. Prezentowała Stefana Żeromskiego jako zwolennika rewolucji i komunizmu ${ }^{8}$, a Henryka Sienkiewicza - jako autora powieści nie najwyższego lotu (Bortnowski 1988: 169-171). Pedagogikę poniżania Polaków, dzielenia społeczeństwa i prowokowania narodowego wstydu realizowano i realizuje się

8 W adaptacji Ludzi bezdomnych zatytułowanej Doktor Judym (Haupe reż. 1974) bohater stał się zwolennikiem rewolucji, czego nie ma w powieści. Żeromski zarówno w Przedwiośniu, jak i w pismach publicystycznych rewolucję potępił. 
nadal w trzech głównych obszarach: antyszlacheckości, antysemityzmu i antypolonizmu. Antynomie wartościowania polskiej szlachty, kultury i państwa oraz literatury stały się edukacyjnym wyzwaniem.

Szlachtę prezentowano w PRL, eksponując jej wady. Były one akcentowane w medialnych przekazach, zwłaszcza w filmowych adaptacjach lektur, oglądanych w trakcie tzw. wyjść do kina, a w późniejszych latach - na lekcjach z zapisu wideo, rzadko z kompetentnym komentarzem nauczyciela, ponieważ wskutek braku filmoznawczego przygotowania nie był on lub nie czuł się kompetentny w tym zakresie. Mimo zniesienia cenzury negatywna ocena polskiej szlachty funkcjonuje w będących nośnikami tego rodzaju wartości podręcznikach ${ }^{9}$, a także w świadomości nauczycieli i kandydatów na nauczycieli ${ }^{10}$.

Do tendencyjnych ocen ważnych bohaterów polskiej literatury przyczyniły się filmowe adaptacje, ponieważ wpisywano w nie zadania propagandowe. I tak np. Tomasz Judym stał się rewolucjonistą w Doktorze Judymie Włodzimierza Haupego (reż. 1974) $)^{11}$, a do Potopu Jerzego Hoffmana (reż. 1974) dopisano scenę „ilustrującą" udział chłopów w oporze przeciwko szwedzkiemu najazdowi ${ }^{12}$, czyniąc z Sienkiewicza demokratę. Natomiast najwybitniejszych wodzów w osobach Stefana Czarnieckiego czy Jerzego Lubomirskiego pominięto, sugerując ocenę szlachty jako zdradzieckiej (jak Janusz Radziwiłł) oraz zniewieściałej (jak Bogusław Radziwiłł), a tym samym imputując Sienkiewiczowi antyszlacheckość. Przyjmując bezkrytycznie wypowiedź Chinua Achebe (1977), okrzyknięto Josepha Conrada rasistą (bloody racist ${ }^{13}$ ), podobnie jak Sienkiewicza za powieść $W$ pustyni i w pusz$c z y$, zapominając o chrześcijańskim i patriotycznym przesłaniu tej powieści ${ }^{14}$ oraz o rasistowskich elementach Robinsona Crusoe Daniela Defoe. Kreon nadal bywa

9 Na przykład Jan Chryzostom Pasek bywa przedstawiany jako szlachecki warchoł i zabijaka. Zapomina się natomiast, że najlepszych jedenaście lat życia oddał swemu krajowi jako żołnierz, a potem pracował jako dobry gospodarz, mąż i odpowiedzialny ojczym (zatem nie tylko przeżywał „traumę”, jak bohaterowie amerykańskich filmów po wojnie w Wietnamie). Paska oskarża się o rabunki, nie dodając, że nie otrzymywał żołdu (por. Ślósarz 1995: 11; Ślósarz 1996: 24; Ślósarz 2013: 319-322; zob. podręcznik: Brożek 2011: 109-111).

10 Wskazują na to moje obserwacje lekcji prowadzonych przez nauczycieli oraz doświadczenia związane z przygotowywaniem studentów do prowadzenia lekcji na temat J.Ch. Paska.

11 W ostatniej scenie Judym wkracza na teren kopalni, niosąc ulotki. Zostaje wpuszczony przez portiera jako osoba zaufana, co oznacza jego dłuższy związek ze środowiskiem rewolucjonistów.

12 Por. w adaptacji Potopu Hoffmana (reż. 1974) scenę, w której Kmicic z kompanami ogląda spaloną przez Szwedów wioskę - cz. II, 12-14 min.

13 Tymczasem opowiadanie Conrada jest wypowiedzią bohatera, nie można zatem przypisywać autorowi jego wartościowań, doświadczeń i sformułowań (zob. Watts 1983: 196-209).

14 Zakończenie, w którym Kali upowszechnia chrześcijaństwo w swym kraju, a Staś i Nel wracają do Polski, to ważne przesłania dla młodzieży. Natomiast obie jej filmowe adaptacje (Ślesicki reż. 1973; Howard reż. 2001) są filmami przygodowymi i pomijają Sienkiewiczowskie zakończenie. 
prezentowany na lekcjach jako zasługujący na śmierć despota, na współczucie zasługuje zaś jedynie Antygona ${ }^{15}$.Z pozamerytorycznych powodów Transatlantyk Witolda Gombrowicza uznano za tekst antypolski ${ }^{16}$. Anachroniczność i nieuprawniony charakter takich interpretacji i ocen wynikają z ulegania najsilniejszym dyskursom medialnym. Brak wiedzy historycznej, historycznoliterackiej i niedokładna znajomość tekstów skutkują ich niezrozumieniem, a co za tym idzie niemożliwością poddania aktualizującym interpretacjom.

Nieuprawnione interpretacje i fałszywe wartości narzucano, eliminując refleksje najwybitniejszych polskich pisarzy, dotyczące społecznej sprawiedliwości i tożsamości narodowej. Realizatorzy Doktora Judyma pominęli fundamentalne dla powieści poglądy inż. Korzeckiego. Kulminacją filmu Hoffmana jest zwrot akcji, dotyczący Kmicica, a nie obrona częstochowskiego klasztoru, ponieważ nie zaadaptowano na ekran kluczowego dla powieści Sienkiewicza przesłania na temat roli polskiego katolicyzmu. Do dziś nie powstały wierniejsze tym powieściom adaptacje.

Absorbujące polską opinię publiczną spory, najpierw na temat negatywnych cech narodowych Polaków, a potem relacji Polaków i Żydów, przeniknęły do szkoły, w tym do szkolnych interpretacji narodowej klasyki. Wprowadzono lektury dotyczące tych problemów (np. Amiel 1999; Krall 1976; Załuski 1962), ale tempo zmian spowodowało, że nauczyciele nie zostali do podejmowania tak złożonej problematyki przygotowani przez uniwersyteckich dydaktyków czy historyków, lecz przez ideowo zaangażowanych publicystów, komercyjne wydawnictwa i intencjonalne produkty światowego przemysłu medialnego, które narzuciły pożądane dla ich twórców czy właścicieli emocje i wzmocniły m.in. bariery „w przyswajaniu pojęć metafizycznych i znaczeń symbolicznych" (Szymik 2005: 183).

Dlatego potrzebne są krytyczne i staranne edycje lektur ze zaktualizowanymi wskazówkami interpretacyjnymi oraz likwidacja podręczników papierowych na rzecz zasobów elektronicznych, obejmujących: propozycje kierunków

15 Wynika to z niezrozumienia konfliktu tragicznego i tym samym z ulegania dominującym w Polsce dyskursom medialnym, w których opozycja krytykuje władzę przy wsparciu ponadnarodowych koncernów medialnych (zob. Lotterhoff i in. red. 2019: 68-73). Autorki odwołały się do plakatu teatralnego, przedstawiającego nieszczęśliwą Antygonę, zaleciły analizę jej emocji (Kreon współczuciu nie podlega), a proponowana na zakończenie lekcji piosenka zawiera w refrenie m.in. kierowane do Kreona słowa: „Bój się teraz ty Kreonie / Nie zaśniesz przeze mnie / [...] Będę ci szeptać przekleństwa do ucha”.

16 W rozporządzeniu Ministra Edukacji Narodowej z dnia 3 lipca 2007 roku, podpisanym przez ówczesnego wicepremiera Romana Giertycha, nie ujęto tej powieści. Wydawnictwo Literackie, mając kontrakt na wydanie dzieł Gombrowicza, inspirowało protesty, np. aranżując wystawy w swej księgarni tak, aby prezentować Transatlantyk jako książkę zakazaną. Prowokowało w ten sposób niemerytoryczne kontrargumenty - oskarżanie powieści o antypolskość. 
interpretacji wynikające z podstawy programowej; projekty celowego powiązania tekstów i dopasowania do nich kontekstów; wzorcowe ćwiczenia, a nawet wybrane teksty wierszy, co eliminuje problemy związane z ich wyszukiwaniem, niestarannością edycji itp. Cyfrowe zasoby łatwo poddają się aktualizacji, uzupełnieniom czy poprawkom, są przystępne dla uczniów i wygodniejsze dla nauczycieli niż podręczniki drukowane. Odkłamanie uproszczonych interpretacji to zadanie fundamentalne w dydaktyce polonistycznej XXI wieku. Młodzi Polacy najczęściej nie znają ani narodowej klasyki literackiej z Panem Tadeuszem Adama Mickiewicza na czele, ani historii swego kraju, dlatego są bezbronni w konfrontacji ze stereotypami na własny temat.

\section{Opracowanie materiału nauczania i zestawu lektur}

Realizacja tych samych celów przy pomocy odmiennych treści dydaktycznych jest możliwa - udowodniła to B. Chrząstowska (red. 1990). Trzeba tylko jasno określić cele i wynikające z nich efekty kształcenia. Materiał nauczania może być wtedy fakultatywny.

Dołączane w XXI wieku do kolejnych podstaw programowych zestawy lektur nieodmiennie stawały się kością niezgody oraz główną przyczyną politycznych i medialnych ataków na te dokumenty. Inspiratorami bywały wydawnictwa, które miały umowy na druk dzieł zakwestionowanych autorów. Emocjonalny poziom dyskursu publicznego oraz pozamerytoryczne argumenty przenoszono na lekcje polskiego i konferencje dydaktyczne. Dydaktycy nie opracowali jednak alternatywnego kanonu lektur szkolnych, który uwzględniałby potrzeby uczniów i specyfikę polskiego pola literackiego w rozumieniu Pierre'a Bourdieu (2007; zob. Gajewski 1997: 255-266; Jankowicz 2017) oraz wyjaśniałby np. szczególne znaczenie nagród literackich w polskich warunkach, mechanizmy ich przyznawania i wyznaczania nimi pól literackich. Trzeba też kontynuować badania literatury dziecięcej i młodzieżowej, zwłaszcza w zakresie jej aksjologii (zob. np. Chrobak 2019; Kwiatkowska-Ratajczak 1994).

W szkołach z maturą międzynarodową poloniści samodzielnie opracowują zestawy lektur. Wzorując się na udostępnionych im materiałach, opracowanych z punktu widzenia Europy Zachodniej, konstruują własne moduły tematyczne z lektur z zaproponowanego zestawu. Wprowadzają w ten sposób na lekcje teksty dawne i współczesne, nie zawsze zdając sobie sprawę, że uczestniczą w globalnej walce dyskursów. Zestawione lektury formują kognitywne amalgamaty i wpływają na ukierunkowanie interpretacji tekstu wyjściowego. Obudowanie Pana Tadeusza fragmentami Pamiętników Jana Chryzostoma Paska, charakteryzującymi go w PRL-owskim duchu tylko jako zabijakę, z pominięciem jego 
zasług jako żołnierza, gospodarza i ojca (por. Ślósarz 1995, 1995), oraz powieścią Michała Witkowskiego pojawiło się w szkole prywatnej (por. Ślósarz 2018: 180). Wraz z zastąpieniem terminu literatura okresu II wojny światowej wyrażeniem literatura okresu Holocaustu albo literatura Wielkiej Wojny Ojczyźnianej świadczy to o niedocenianiu lub niezrozumieniu potrzeby narodowej tożsamości, odrębności i życia wspólnotowego, coraz częściej zastępowanych w globalnym dyskursie ideami narodu jako wspólnoty wyobrażonej (Anderson 1997) czy społeczeństwa sieciowego (zob. np. Castells 2008; de Kerckhove 2001). Prowadzi też do nazwania Krzysztofa Kamila Baczyńskiego przez nauczyciela „poetą okresu Holocaustu" (przypadek autentyczny).

\section{Upowszechnienie multimedialnych form wypowiedzi}

Skoro współczesna literatura stała się intertekstualna (zob. np. Culler 1980: 299-312; Głowiński 1986: 75-100; Hutcheon 1997: 378-420; Kristeva 2002: 7-13; Nycz 1993: 79-109; Nycz 2006: 153-180; Pfister 1991: 183-208; Riffaterre 1984: 142-143) i paraaudiowizualna (Hopfinger 2003: 155), to jej percepcja obejmuje multimedialne konteksty. Dziś już każdy podręcznik i każdy polonista odwołuje się do malarstwa. Elementami porównań stają się też teksty multimedialne: filmy, teledyski, animacje itp. Wyzwalają one zainteresowanie i zaangażowanie uczniów w procesie kształcenia, stymulują aktywność mózgową (analiza, synteza, abstrahowanie, uogólnianie) (Yordanova 2012: 412) oraz pobudzają do współpracy, np. w przypadku nagrywania filmu albo słuchowiska.

Percepcja multimediów jest odzwierciedleniem, a nie przyczyną zmian komunikacyjnych, społecznych i kulturowych. Skoro czytanie i pisanie są postrzegane przez przedstawicieli New Literacy Studies (np. Gee 1990; Street 2004: 326-330) w kontekstach instytucjonalnych i jako praktyki społeczne, to również multimedialne formy wypowiedzi należy rozważać jako osadzone w kontekstach kulturowych. Nie wszystkie myśli da się wyrazić multimediami, dlatego konieczne jest też rozwijanie sprawności mówienia i pisania. Komunikowanie staje się jednak coraz bardziej multimedialne i do tego polscy uczniowie powinni być przygotowani, aby potrafili być jego aktywnymi podmiotami, a nie tylko odbiorcami.

Tymczasem konformistyczni egzaminatorzy ${ }^{17}$ nie poradzili sobie z problemem kopiowania prezentacji Power Point i doprowadzili do usunięcia ich

17 Konformizm egzaminatorów polegał na uległości wobec oczekiwań środowiskowych ocen negatywnych nie wystawiali nawet w przypadku stwierdzenia niesamodzielności prezentacji, ponieważ obawiali się reakcji rodziców, dyrekcji (dbającej o dobry nabór uczniów do „przyjaznej szkoły”) i Okręgowej Komisji Egzaminacyjnej, która czasem mało przekonujące odwołania 
z ustnego egzaminu maturalnego w 2015 roku. Wraz z gimnazjami znikły dwa lata później przygotowywane zespołowo multimedialne wypowiedzi powiązane z różnymi przedmiotami. Polski uczeń już nie tworzy obowiązkowych prezentacji multimedialnych, lecz głównie je odbiera, traktując Internet jak bibliotekę. Nie jest więc przygotowany do tworzenia własnego dyskursu w Sieci ani w siatce konkurencyjnych dyskursów.

Media stały się nośnikami wartości, jednak dydaktyka polonistyczna nie upowszechniła strategii wykorzystania multimediów ani do kształcenia form wypowiedzi, ani do aktualizowania interpretacji, poszerzania odniesień i pogłębiania rozumienia tekstów literackich.

\section{Wprowadzenie cyfrowych narzędzi edukacyjnych}

Pandemia udowodniła, że dydaktyka polonistyczna za słabo odnosi się do kształcenia na odległość ${ }^{18}$, które dynamicznie rozwija się w świecie w postaci np. Khan Academy, platform Edx, Coursera i licznych Massive Open Online Courses (zob. Gurba 2015). Niewielu uniwersyteckich dydaktyków prowadziło przed pandemią kształcenie na odległość, choć coraz częściej było ono praktykowane w szkołach. Najbardziej zaawansowane technologicznie rozwiązania wciąż wdrażają uczelnie techniczne, biznes, handel i przemysł. Cyfrowe narzędzia dydaktyki polonistycznej są proponowane przez osoby funkcjonujące w środowisku dydaktycznym i biznesowym bądź dydaktycznym i oświatowym (np. Kopacz 2017; Kulig-Kozłowska 2017; Poręba 2014a), ale nie prowadzi się badań nad ich skutecznością. Dydaktyka polonistyczna wypracowała więc niewiele narzędzi adekwatnych do potrzeb, zainteresowań, zdolności i aspiracji współczesnych uczniów, a także do poziomu rozwoju technologicznego i form współczesnego komunikowania się oraz postaci literatury XXI wieku.

Inne kraje, jak np. Australia, w ramach nauki języka ojczystego kształcą nie tylko umiejętność wypowiadania się w formie mówionej i pisanej, lecz także obowiązkowo przygotowywanie wypowiedzi multimedialnych (tzw. responding) (English Standard Stage 6. Draft Syllabus... 2017: 4, 16). Tworzenie wypowiedzi w cyfrowym środowisku przysposabia uczniów do niezbędnego współczesnemu

\footnotetext{
uczniów rozpatrywała na ich korzyść. W efekcie większość egzaminatorów przestała wystawiać oceny negatywne, a ci, którzy je wystawiali, byli odsuwani od pracy w komisji egzaminacyjnej na prośbę uczniów jako „zbyt wymagający”. Gdy następnie rzetelność egzaminu miał zapewniać członek komisji z innej szkoły, zaczęto wymieniać się egzaminatorami na zasadzie wzajemnego lobbingu (por. Ślósarz 2006: 59-61; Ślósarz 2008a: 400-408).

18 Nieliczne są autorskie publikacje polonistów na ten temat (zob. np. Dziak 2012; Ślosarz 2008b).
} 
człowiekowi poznawania środków wyrazowych i krytycznego odbioru multimedialnych form wypowiedzi. Przygotowywane były one również przez polskich uczniów na potrzeby prezentacji gimnazjalnych i maturalnych. W efekcie ich zniesienia polscy uczniowie traktują Sieć jak źródło informacji. Taka luka kompetencyjna w społeczeństwie jest niebezpieczna w obliczu wojen informacyjnych (zob. np. Lakomy 2015), a także wytwarzania dezintegrujących społeczeństwa baniek informacyjnych oraz fake newsów, generujących dla ich twórców korzyści prestiżowe, finansowe i polityczne kosztem rozemocjonowanych odbiorców. Tzw. strajk kobiet z końca 2020 roku pokazał, że już można medialnie sterować tzw. gimbaza (młodzieżą w wieku gimnazjalnym).

Niedostatek wykorzystywania nowych technologii dotyczy też procesu kształcenia kandydatów na nauczycieli języka polskiego. Hospitowanie studenckich praktyk stało się tak uciążliwe, że coraz częściej się z niego rezygnuje. Nie są wykorzystywane doświadczenia zachodnich uniwersytetó $w^{19}$, które radzą sobie z hospitowaniem lekcji nawet na innych kontynentach, np. wykorzystując darmową aplikację Veo stworzoną przez Veo Group (www.veo-group.com). Można przy jej pomocy tagować sfilmowane zdarzenia lekcyjne i wpisywać objaśnienia do filmów, rejestrujących kluczowe części lekcji, jak wprowadzenie, podział zadań, przykładowe działania uczniów, podsumowanie lekcji przez ucznia. Aplikacja ułatwia więc wspólne omawianie lekcji. Dydaktycy nie muszą być obciążeni podróżami, mogą zyskać czas na opracowywanie nowych strategii, metod i narzędzi kształcenia. Brak zainteresowania dydaktyków kształceniem w cyfrowym środowisku skutkuje redukcją humanistycznych aspektów kształcenia na odległość oraz jego algorytmizacją, która dehumanizuje pracowników i kontakty społeczne (por. Ślósarz 2017: 27-45).

\section{Współpraca z władzami, wydawnictwami i biznesem elektronicznym}

Dobra współpraca jest owocna dla każdego z podmiotów, dlatego rozwijanie jej jest charakterystyczne dla krajów o najlepszym poziomie rozwoju edukacji, a ten zawsze idzie $\mathrm{w}$ parze $\mathrm{z}$ wysokim poziomem rozwoju państwa (United Nations Development Programme 2018: 54). Dobrą praktyką są w Norwegii seminaria śniadaniowe, organizowane przez regionalne firmy sektora prywatnego i ich ośrodki badawcze, dla nauczycieli i dyrektorów szkół. Praktycy prezentują podczas nich najnowsze rozwiązania technologiczne: cyfrowe materiały edukacyjne, systemy monitorowania i narzędzia do analizy uczenia się (Smart og

19 Na przykład Durham University, Newcastle University, Universidad de Barcelona, University of Hull, University of Lapland, University of Sunderland, University of South Wales. 
enkel teknologi for laring 2015). Rząd Szwajcarii organizuje adresowane do firm branży Edu-Tech konkursy na najlepsze cyfrowe narzędzia dydaktyczne (Neues EdTech Vertical... 2017). Australijskie programy kształcenia zawierają adresy bibliograficzne najlepiej wydanych i opracowanych lektur, co rodzi wśród wydawców zdrową konkurencję. Inicjatywy tego rodzaju owocują dla podmiotów biznesowych nagrodami, kontaktami z ekspertami i poszerzeniem rynku zbytu, rząd może poszczycić się skutecznym wypełnianiem swych zadań, a oświata zyskuje nowoczesne narzędzia.

Lekcje odbywające się częściowo w środowisku cyfrowym bardzo angażują uczniów, np. konstruowanie w Facebooku (por. Kulig-Kozłowska 2017) profili bohaterów literackich czy interpretowanie wierszy narzędziami do tworzenia chmur wyrazowych (por. Ślósarz 2019). Ich działania przy użyciu złożonych technologii nie są do końca autorskie, ale utrwalają wiedzę, rozwijają umiejętności i kształcą społeczne kompetencje, wyzwalając potencjał uwidoczniony w dolnych partiach stożka Dayle'a (zob. The Learning...).

W Polsce brakuje współpracy oświaty i biznesu elektronicznego. Nauczyciele wykorzystują narzędzia amerykańskich koncernów, jak Microsoft (zwłaszcza Microsoft Teams), Google lub Apple i takie są omawiane na konferencjach dydaktycznych (np. na IV Kongresie Dydaktyki Polonistycznej). Przestali pojawiać się na nich polscy twórcy cyfrowych narzędzi edukacyjnych. Nauczyciele używający iTunesU automatycznie promują markę Apple. Uczniowie filmujący np. wywiad w aplikacji TikTok (Google Play) oglądają przy tym filmiki realizowane w celach rozrywkowych, ponieważ współpraca edukacji z e-biznesem jest w Polsce niewystarczająca.

Tymczasem w 2019 roku w niemieckiej Hesji zakazano szkołom używania pakietu Office 365 z uwagi na naruszenia prywatności - obecnie dane muszą być rejestrowane na serwerach w Niemczech, aby podlegały niemieckiemu prawu (Oates 2019). W Polsce lekcje odbywające się przy użyciu usługi Microsoft Teams skutkują rejestrowaniem wizerunków i danych telemetrycznych w chmurze, czyli na serwerach w USA, podczas gdy sprzedawane są usługi rozpoznawania twarzy miliardów ludzi (np. FindFace).

\section{Wykorzystywanie badań edukacyjnych}

Badania edukacyjne są domeną dydaktyków, którzy mają kontakt z uczniami w ramach studenckich praktyk i innych typów współpracy ze szkołami. Wycinkowe eksploracje nie są jednak koordynowane, toteż zarówno badania, jak i publikacje pozostają rozproszone. Służą one w efekcie nie tyle środowisku edukacyjnemu, co środowisku dydaktycznemu. Zadania badawcze przejął Instytut Badań 
Edukacyjnych, a także Ośrodek Rozwoju Edukacji. Instytucjonalne rozproszenie nie służy współpracy. Tymczasem na zachodzie Europy wymusza się prowadzenie badań edukacyjnych m.in. $w$ ten sposób, że na konferencje przyjmowane są wyłącznie artykuły oparte na badaniach, najlepiej ukończonych (np. ARLE Conference and Research School 2019 w Lizbonie). Odniesienia do badań występują w nazwach międzynarodowych stowarzyszeń (np. International Association...) i konferencji (np. 10. Międzynarodowa Konferencja „Education, Research \& Development”, Burgas, Bułgaria, 23-27 sierpnia 2018 roku). Upowszechniane są więc najnowsze wyniki, metodologie i technologie badań edukacyjnych.

Badania jakości kształcenia prowadzone są przez niewielu dydaktyków - głównie tych, którzy są czynnymi nauczycielami. W efekcie podstawy programowe nie są oparte na badaniach, toteż są przez środowiska dydaktyków krytykowane jako przejawy niekompetencji lub stronniczości każdej kolejnej władzy państwowej. Tymczasem mogłyby być przez wszystkie zainteresowane środowiska współtworzone przez prowadzenie i udostępnianie badań: potrzeb, możliwości i oczekiwań uczniów. Okazuje się na przykład, że 88,88\% ankietowanych uczniów uznało, iż głośne przeczytanie na lekcji Króla Edypa spowodowało, że tekst ich zaciekawił, został lepiej zrozumiany i przeżyty, pobudził wyobraźnię, zintegrował klasę, dał sposobność do zadawania pytań, co pomogło w napisaniu sprawdzianu. Ankieta ujawniła zapotrzebowanie uczniów na dogłębne poznawanie literatury i odwoływanie się do jej estetycznych, terapeutycznych i integrujących jakości ${ }^{20}$. Podobne doświadczenia ma wielu szkolnych polonistów, ale rzadko są one badane i publikowane.

\section{WNIOSKI: WARUNKI OPŁACALNOŚCI I WYPŁACALNOŚCI OBLIGACJI}

Humanistyka, w tym nauczanie języka polskiego, ma wymiar wspólnotowy: może wzmacniać spójność społeczną, chronić pamięć kulturową, uczyć krytycznego myślenia i przyczyniać się do duchowego rozwoju jednostek (Kozłowski 2016: 188-194). Spełnianie zadań społecznych jest warunkiem opłacalności obligacji dydaktycznych. Mimo że dydaktyka polonistyczna nie jest przez uniwersyteckich dydaktyków dopracowana, a przez władze nie jest zorganizowana i finansowana na tak wysokim poziomie, jak np. niemiecka czy australijska, to

20 W Prologu Kapłan wraz z ludem prosi Edypa o ratunek, ponieważ zaraza „wszystkie domy gnębi” z powodu grzechu zabójstwa Laiosa. Chór stwierdzając, że „stosy trupów po ulicach leżą”, wzywa bogów do ukarania zabójcy i przywrócenia porządku. Wypowiedzi te mają ogromny potencjał moralny, filozoficzny i społeczny, zauważalny przy głośnym czytaniu (aktualnie w kontekście pandemii i tzw. strajku kobiet), lecz prawdopodobnie niezrozumiały w czytaniu cichym z uwagi na najczęściej przez uczniów używane tłumaczenie autorstwa Kazimierza Morawskiego. 
wielu szkolnych polonistów wypełnia swe społeczne zadania z takim samym zaangażowaniem, jak zagraniczni koledzy. Jednocześnie strajki polskich nauczycieli dowodzą, że obligacje dydaktyki tracą wartość, gdy nie spełnia ona swych społecznych zobowiązań.

Nauczyciele języka polskiego przekazują cenny kapitał społeczny ${ }^{21} \mathrm{i}$ kulturo$w^{22}$, dlatego są zwykle najlepiej pamiętani przez uczniów, choć bywają przez nich doceniani dopiero po latach. Organizując życie kulturalne szkoły i wprowadzając w świat dawnej i współczesnej kultury, realizują zadania dydaktyczne: prezentują obywatelskie myślenie, pokazują wyobrażenia o Polsce i realizują wychowanie. Mają świadomość, że dobra edukacja przynosi wszystkim korzyści, które - tak jak w przypadku posiadania obligacji - są odroczone i wzrastają z upływem czasu. Polonistyczna dydaktyka posiada, a państwo przechowuje i rozdysponowuje kapitał, który może zostać wykorzystany wtedy, gdy stanie się niezbędny do dalszego funkcjonowania. Stało się tak, gdy całe pokolenia Polaków kształconych w dwudziestoleciu międzywojennym na romantycznych tekstach nie zawahały się stanąć w obronie swego kraju podczas II wojny światowej. Równie skuteczna dydaktyka polonistyczna potrzebna jest dziś, gdy popkultura kształtuje tożsamość globalnych nastolatków, a ponadnarodowe koncerny medialne i wojny informacyjne zagrażają narodowej spójności.

Wszystkie organy i obszary funkcjonowania państwa (w tym sektor edukacji) winny spełniać swe zadania. To warunek wypłacalności obligacji. Dlatego społeczne, moralne i kulturowe zobowiązania dydaktyki polonistycznej trzeba traktować odpowiedzialnie i dalekowzrocznie.

\section{BIBLIOGRAFIA}

\section{Literatura}

Achebe, Ch. (1977). An Image of Africa: Racism in Conrad's 'Heart of Darkness'. Massachusetts Review, no. 18, 1783-1794.

Adamczyk, M., Chrząstowska, B., Pokrzywniak, J.T. (1987). Starożytność - oświecenie:

podręcznik literatury dla klasy pierwszej szkoty średniej. Warszawa: WSiP.

Amiel, I. (1999). Osmaleni. Izabelin: Świat Literacki.

21 Kapitał społeczny w ujęciu Roberta Putnama i Jamesa Colemana odnosi się do budowania relacji, norm, powiązań i zaufania społecznego, dzięki którym jednostki i społeczeństwa koordynują działania i osiągają wielorakie korzyści.

22 Kapitał kulturowy w rozumieniu Pierre'a Bourdieu i Jean-Claude'a Passerona (1970) to niezbywalne dyspozycje jednostki w postaci jej dobrych manier, umiejętności, kompetencji, wiedzy, wykształcenia i posiadanych przedmiotów kulturowych. 
Anderson, B. (1997). Wspólnoty wyobrażone: rozważania o źródtach i rozprzestrzenianiu się nacjonalizmu. Kraków: Społeczny Instytut Wydawniczy Znak.

Antosik, C. (1999). Czytam świat. Wypisy z wielkiej księgi kultury. Podręcznik do ksztatcenia literacko-kulturowego dla klasy I gimnazjum. Kielce: Wydawnictwo Pedagogiczne ZNP.

Balicki, J., Makowski, S. (1943). Mówiq wieki. Podręcznik do nauki języka polskiego dla II klasy gimnazjalnej. Jerozolima: nakł. Komisji Regulaminowo-Wydawniczej Armii Polskiej na Wschodzie.

Barton, D., Hamilton, M. (2003). Local Literacies: Reading and Writing in One Community. London: Routledge.

Barton, D., Hamilton, M., Ivanic, R. (eds.). (2005). Situated Literacies. Reading and Writing in Context. London: Routledge.

Biała, A., Krawczyk, A. (2002). Język, literatura, kultura. Wypisy i zadania. Podręcznik do języka polskiego dla klasy I liceum ogólnokształcacego (zakres podstawowy i rozszerzony), liceum profilowane i technikum. Kielce: Wydawnictwo Pedagogiczne ZNP.

Biedrzycki, K., Jaskółowa, E., Nowak, E. (2012). Świat do przeczytania (Cz. 1: Kultura, jezyk, dialogi). Warszawa: PWN.

Bortnowski, S. (1988). „Potop” w szkole. Odbiór powieści Henryka Sienkiewicza. Wnioski dydaktyczne. Warszawa: WSiP.

Bourdieu, P. (2007). Reguty sztuki. Geneza i struktura pola literackiego. Kraków: TAiWPN Universitas.

Bourdieu, P., Passeron, J.-C. (1970). Reproduction in Education, Society and Culture. London: Sage Publications.

Brożek, A. (2011). Swoimi stowami. Podręcznik do ksztatcenia literackiego i kulturowego wraz ze szkoła pisania, język polski dla gimnazjum, klasa 3. Warszawa: Nowa Era.

Bryzek, R. (2016). Śladami autorów, bohaterów, tekstów - questing jako narzędzie w edukacji humanistycznej. W: R. Bomba, A. Radomski, E. Solska (red.), Humanistyka cyfrowa. Badanie tekstów, obrazów i dźwięku (s. 42-51). Lublin: E-naukowie.

Castells, M. (2008). Społeczeństwo sieci. Warszawa: PWN.

Chmiel, M. (2009). Stowa na czasie. Podręcznik do ksztatcenia literackiego i kulturowego dla klasy pierwszej gimnazjum. Warszawa: Nowa Era.

Chmiel, M., Równy, A. (2019). Ponad słowami. Podręcznik do języka polskiego dla liceum ogólnoksztatcacego i technikum: zakres podstawowy i rozszerzony: klasa 1. Cz. 2. Warszawa: Nowa Era.

Chrobak, M. (2019). Bohater prozy dziecięcej okresu PRL-u. Między kreacją a recepcją. Kraków: Uniwersytet Pedagogiczny w Krakowie.

Chrząstowska, B. (1979). Teoria literatury w szkole. Z badań nad recepcją liryki. Wrocław: Zakład Narodowy im. Ossolińskich - Wydawnictwo PAN.

Chrząstowska, B. (1988). O interpretacjach porównawczych. W: B. Chrząstowska, T. Kostkiewiczowa (red.), Olimpiada Literatury i Języka Polskiego. Zatożenia oceny - postulaty (s. 122-148). Warszawa: WSiP.

Chrząstowska, B. (2002). Skarbiec języka, literatury, sztuki. Wypisy z ćwiczeniami. Podręcznik dla klasy I liceum ogólnokształcacego i profilowanego. Zakres podstawowy i rozszerzony. Kultura XX wieku i jej tradycje. Poznań: Wydawnictwo Nakom. 
Chrząstowska, B. (2009). O interpretacji porównawczej - po latach. W: M. Kwiatkowska-Ratajczak, W. Wantuch (oprac.), Przedmiot, podmiot i proces. Szkice $z$ metodyki ksztatcenia polonistycznego (s. 115-121). Poznań: Poznańskie Studia Polonistyczne (pierwodruk: Polonistyka 1997, nr 3, 166-171).

Chrząstowska, B. (red.). (1990). Program liceum ogólnokształcącego, liceum zawodowego i technikum - język polski (dwie wersje). Warszawa: WSiP.

Chrząstowska, B. (red.). (1995). Podstawa programowa języka polskiego (1995). Polonistyka, nr 5, 317-330.

Chrząstowska, B. (red.). (2002). Skarbiec języka, literatury, sztuki. Podręcznik dla klas I-III liceum ogólnokształcącego i profilowanego. Zakres podstawowy i rozszerzony. Poznań: Wydawnictwo Nakom.

Culler, J. (1980). Presupozycje i intertekstualność. Pamiętnik Literacki, nr 3, 297-312.

Drabik-Frączek, B., Pstrąg, J., Zawadzki, A. (2007). Klucz do świata. Literatura, język, komunikacja. Podręcznik do języka polskiego. Szkoty ponadgimnazjalne. Zakres podstawowy i rozszerzony. Klasa I, część I. Warszawa: Wydawnictwo Szkolne PWN.

Dyduch, B., Kłakówna, Z.A., Jędrychowska, M. (1994). To lubię! Podręcznik do języka polskiego dla klasy IV - teksty i zadania. Książka ucznia. Kraków: Wydawnictwo Edukacyjne (współautorzy serii podręczników i ich obudowy metodycznej dla szkoły podstawowej, gimnazjum i szkoły ponadgimnazjalnej: M. Jędrychowska, Z.A. Kłakówna, P. Kołodziej, W. Martyniuk, H. Mrazek, M. Potaś, I. Steczko, E. Szudek, J. Waligóra).

Dyduchowa, A. (1988). Metody kształcenia sprawności językowej uczniów: projekt systemu, model podręcznika. Kraków: Wydawnictwo Naukowe WSP.

Dziak, A. (2012). Edukacja polonistyczna w dobie digitalizacji. Lublin: Wydawnictwo KUL.

Eco, U., Rorty, R., Culler, J., Brooke-Rose, Ch., Collini, S. (red.). (2008). Interpretacja $i$ nadinterpretacja. Kraków: Wydawnictwo Znak.

English Standard Stage 6. Draft Syllabus. Consultation Report February 2017. Pobrane z: http://educationstandards.nsw.edu.au/wps/wcm/connect/2cd15448-c25c4113-b202-e60d7bd78977/english-standard-stage-6-draft-syllabus-consultation -report-2017.pdf?MOD=AJPERES\&CVID [dostęp: 20.01.2020].

Fish, S. (1980). Is There a Text in This Class? The Authority of Interpretive Communities. Cambridge: Harvard University Press.

Fiszbak, J. (red.). (2019). Polonistyczna dydaktyka ogólna. Łódź: Wydawnictwo Uniwersytetu Łódzkiego.

Gajewski, K. (1997). „Reguły sztuki: geneza i struktura pola literackiego”, Pierre Bourdieu, przeł. Andrzej Zawadzki, red. nauk. Małgorzata Sugiera, Kraków 2001: [recenzja]. Pamiętnik Literacki, nr 2, 255-266.

Garsztka, T., Olszowska, G., Dziuba, Z. (1999). Do Itaki. Z XX i XXI wieku. Ksztatcenie literacko-kulturowe. Podręcznik dla ucznia. 1 klasa gimnazjum. Kraków: Społeczny Instytut Wydawniczy Znak.

Gee, J.P. (1990). Social Linguistics and Literacies: Ideology in Discourses. London: Routledge.

Głowiński, M. (1986). O intertekstualności. Pamiętnik Literacki, nr 4, 75-100. 
Gurba, K. (2015). MOOC. Historia i przyszłość. Kraków: Uniwersytet Papieski Jana Pawła II.

Wydawnictwo Naukowe.

Haupe, W. (reż.). (1974). Doktor Judym.

Hofman, J. (reż.). (1974). Potop.

Hopfinger, M. (2003). Doświadczenia audiowizualne. O mediach w kulturze wspótczesnej.

Warszawa: Wydawnictwo Sic!

Howard, G. (reż.). (2001). W pustyni i w puszczy.

Hutcheon, L. (1997). Historiograficzna metapowieść: parodia i intertekstualność historii. W: R. Nycz (red.), Postmodernizm. Antologia przekładów (s. 378-420). Kraków: Wydawnictwo Baran i Suszczyński.

International Association for Research in L1 Education. Pobrane z: www.arle.be/index.html [dostęp: 20.01.2020].

Jankowicz, G. (2017). Literatura polska po 1989 roku w świetle teorii Pierre’a Bourdieu. Raport z badań. Kraków: Korporacja Ha!art.

Jazownik, L. (2004). Wyzwolić moc lektury. Aksjologiczno-dydaktyczny sens dzieta literackiego. Zielona Góra: Oficyna Wydawnicza Uniwersytetu Zielonogórskiego.

Jazownik, L. (2011). W kręgu historii i teorii edukacji polonistycznej. Zielona Góra, Warszawa: Księgarnia Akademicka.

Jazownik, L. (red.). (2001a). Teoria ksztatcenia literackiego w latach 1918-1939. Antologia (Cz. 1). Zielona Góra: Uniwersytet Zielonogórski.

Jazownik, L. (red.). (2001b). Teoria ksztatcenia literackiego w latach 1918-1939. Antologia (Cz. 2). Zielona Góra: Uniwersytet Zielonogórski.

Jędrychowska, M. (1996). Najpierw cztowiek. Szkolna edukacja kulturowo-literacka a problem kształcenia dydaktycznego polonistów. Refleksja teleologiczna. Kraków: Wydawnictwo Edukacyjne.

Kania, A. (2015). „Polak mtody” na lekcjach jezzyka polskiego. Edukacja polonistyczna a kształtowanie poczucia tożsamości narodowej. Kraków: TAiWPN Universitas.

Kania, A. (2016). Niewykorzystany potencjał „W pustyni i w puszczy” Henryka Sienkiewicza w kontekście kształtowania tożsamości narodowej i kulturowej. Dydaktyka Polonistyczna, nr 2, 54-53.

Kerckhove, D. de (2001). Inteligencja otwarta. Narodziny społeczeństwa sieciowego. Warszawa: Mikom.

Koc, K. (2018a). Lekcje myślenia obywatelskiego. Edukacja polonistyczna wobec wspótczesnego świata. Poznań: Wydawnictwo Naukowe Uniwersytetu im. Adama Mickiewicza.

Koc, K. (2018b). Software w szkolnym kształceniu polonistycznym, czyli o znaczeniu aktualizacji teorii dydaktycznych. Polonistyka. Innowacje, nr 7, 71-83.

Kopacz, A. (2017). Środowisko cyfrowe w edukacji polonistycznej na etapie ponadgimnazjalnym. Lublin: Towarzystwo Naukowe KUL.

Kozłowski, J. (2016). Co z tą polską humanistyką? W: R. Bomba, A. Radomski, E. Solska (red.), Humanistyka cyfrowa. Badanie tekstów, obrazów i dźwięku (s. 188-194). Lublin: E-naukowiec. Pobrane z: http://e-naukowiec.eu/humanistyka-cyfrowa-badanie-tekstow-obrazow-i-dzwieku [dostęp: 20.11.2020].

Krall, H. (1976). Zdążyć przed Panem Bogiem. Odra, nr 4, 3-11; nr 5, 33-40; nr 6, 33-39; nr 7-8, 13-21. 
Kristeva, J. (2002). "Nous Deux" or a (hi)story of intertextuality. The Romanic Review, no. $1-2,7-13$.

Kulig-Kozłowska, A. (2017). Facebook w szkolnej ławce. Media społecznościowe a edukacja polonistyczna. Kraków: TAiWPN Universitas.

Kwiatkowska-Ratajczak, M. (1994). Z perspektywy wartości. O prozie dla dzieci i młodzieży. Poznań: Wydawnictwo Nakom.

Lakomy, M. (2015). Cyberprzestrzeń jako nowy wymiar rywalizacji i wspótpracy państw. Katowice: Wydawnictwo Uniwersytetu Śląskiego.

Lotterhoff, M., Sucharska, B., Kuchta, J., Wojciechowska, A., Zabrodzka, J. (red.). (2019). Ponad stowami 1. Cz. 1: Książka nauczyciela. Materiaty dydaktyczne do języka polskiego dla liceum ogólnokształcącego i technikum. Zakres podstawowy i rozszerzony. Warszawa: Nowa Era.

Łuczak, A., Prylińska, E., Maszka, R. (2002). Język polski. Między nami. Podręcznik dla klasy pierwszej gimnazjum. Gdańsk: Gdańskie Wydawnictwo Oświatowe.

Łuczewski, M., Bednarz-Łuczewska, P. (2012). Analiza dokumentów zastanych. W: D. Jemielniak (red.), Badania jakościowe. Metody i narzędzia (T. 2; s. 163-188). Warszawa: PWN.

Markiewicz, H. (1996). O falsyfikowaniu interpretacji literackich. Pamiętnik Literacki, nr $1,59-74$.

Marohasy, J. (ed.). (2017). Climate Change: The Facts 2017. Melbourne: Connor Court Publishing Pty Ltd.

Modules. (2017). Pobrane z: http://educationstandards.nsw.edu.au/wps/portal/nesa/1112/stage-6-learning-areas/stage-6-english/english-studies-2017/modules [dostęp: 20.01.2020].

Morbitzer, J. (2014). O wychowaniu w świecie nowych mediów - zarys problematyki. Labor et Educatio, nr 2, 119-143.

Mudyń, K. (1995). O granicach poznania. Między wiedza, niewiedza i antywiedza. Kraków: Oficyna Wydawnicza Impuls.

Neues EdTech Vertical: Kickstart Accelerator heisst Startups im Bereich Bildungstechnologie willkommen. 2017. Pobrane z: https://kickstart-innovation.com/wp-content/ uploads/2017/02/170614_Medienmitteilung_Kickstart-Accelerator-heisst-Startupsim-Bereich-Bildungstechnologie-willkommen.pdf [dostęp: 20.01.2020].

Niemczyńska, M., Friedmann, D. (2002). Człowiek w świecie tradycji. Język polski 1. Zakres rozszerzony. Podręcznik dla liceum ogólnokształcącego. Gdynia: Wydawnictwo Pedagogiczne Operon.

Nycz, R. (1993). Intertekstualność i jej zakresy: teksty, gatunki, światy. W: tegoż, Tekstowy świat. Poststrukturalizm a wiedza o literaturze (s. 79-109). Warszawa: Wydawnictwo IBL PAN.

Nycz, R. (2000). Tekstowy świat. Poststrukturalizm a wiedza o literaturze. Kraków: TAiWPN Universitas.

Nycz, R. (2006). Poetyka intertekstualna: tradycje i perspektywy. W: M.P. Markowski, R. Nycz (red.), Kulturowa teoria literatury. Główne pojęcia i problemy (s. 153-180). Kraków: TAiWPN Universitas.

Oates, J. (2019). Office 365 verboten in Hessen schools: German state bans cloudy Microsoft suite on privacy grounds. Pobrane z: www.theregister.com/2019/07/16/ germany_outlaws_office_365_for_school_use [dostęp: 20.11.2020].

Okoń, W. (1987). Wprowadzenie do dydaktyki ogólnej. Warszawa: PWN. 
Pasterski, M. (2017). 13 btędów polskiego sytemu edukacji. Pobrane z: https://michalpasterski.pl/2014/04/13-bledow-polskiego-systemu-edukacji [dostęp: 20.01.2020].

Peplow, D., Swann, J., Trimarco, P., Whiteley, S. (2016). The Discourse of Reading Groups. Integrating Cognitive and Sociocultural Perspectives. New York: Routledge.

Pfister, M. (1991). Koncepcje intertekstualności. Pamiętnik Literacki, nr 4, 183-208.

Podstawa programowa $z$ komentarzami (T. 2: Jezzyk polski w szkole podstawowej, gimnazjum i liceum). (2009). Pobrane z: www.bc.ore.edu.pl/Content/232/ Tom $+2+\mathrm{J} \%$ C4\%99zyk+polski+w+szkole+podstawowej\%2C+gimnazjum+i+liceum. pdf [dostęp: 20.01.2020].

Poręba, A. (2014a). Dydaktyczna aktywność sieciowa nauczycieli polonistów na poziomie gimnazjalnym. Lublin (niepublikowana praca doktorska).

Poręba, A. (2014b). Praca w chmurze jako element nauki języka polskiego w gimnazjum. W: K. Biedrzycki, A. Kania, E. Strawa-Kęsek (red.), Polonistyka dziś - ksztatcenie dla jutra (T. 2; s. 101-111). Kraków: TAiWPN Universitas.

Riffaterre, M. (1984). Intertextual Representation: On Mimesis as Interpretive Discourse. Critical Inquiry, no. 1, 142-143, DOI: https://doi.org/10.1086/448279.

Rosiek, S., Maćkiewicz, J., Majchrowski, Z. (2002). Między tekstami. Język polski. Podręcznik dla liceum i technikum. Zakres podstawowy i rozszerzony. Część 1. Poczatki. Średniowiecze (echa wspótczesne). Gdańsk: Gdańskie Wydawnictwo Oświatowe.

Smart og enkel teknologi for laring. (2015). Pobrane z: www.inspiria.no/?itemid=3001 [dostęp: 20.01.2020].

Street, B. (2004). Futures of the ethnography of literacy. Language \& Education. An International Journal, vol. 18(4), 326-330, DOI: https://doi.org/10.1080/09500780408666885.

Szulc, M., Gorzałczyńska-Mróz, A. (2010). Swoimi stowami. Podręcznik do kształcenia językowego z ćwiczeniami. Warszawa: Nowa Era.

Szymik, E. (2005). Bariery w odbiorze lektur szkolnych. Nauczyciel i Szkoła, nr 1-2, 181-193.

Ślesicki, W. (reż.). (1973). W pustyni i w puszczy.

Ślósarz, A. (1995). Pasek - Sarmata - historia. Wiadomości Kulturalne, nr 45, 11.

Ślósarz, A. (1996). Trwałość czarnej legendy baroku. Wiadomości Kulturalne, nr 2, 24.

Ślósarz, A. (2006). O zewnętrzne ustne prezentacje maturalne. Polonistyka, nr 6, 59-61.

Ślósarz, A. (2008a). Jak ratować ustna maturę? Pobrane z: www.ptde.org/file.php/1/ Archiwum/XIV_KDE/slosarz.pdf [dostęp: 20.01.2020].

Ślósarz, A. (2008b). Media w stużbie polonisty. Kraków: Wydawnictwo Naukowe Akademii Pedagogicznej.

Ślósarz, A. (2013). Ideologiczne matryce. Lektury i ich konteksty. Postkomunistyczna Polska - postkolonialna Australia. Kraków: TAiWPN Universitas.

Ślósarz, A. (2017). Global Prospects of Distance Education. International Journal of Research in E-learning, no. 3, 27-45.

Ślósarz, A. (2018). Produkty przemystu medialnego - interpretanty lektur. MMT jako dydaktyczny instrument. Kraków: Wydawnictwo Naukowe Uniwersytetu Pedagogicznego.

Ślósarz, A. (2019). Metoda wizualizacji słów kluczowych wiersza. W: M. Trysińska, K. Maciejak (red.), Kompetencje nauczyciela polonisty we wspótczesnej szkole. Między schematem a kreatywnościa (s. 207-241). Warszawa: Wydawnictwa Uniwersytetu Warszawskiego. 
The Learning Pyramid. Pobrane z: www.educationcorner.com/the-learning-pyramid. html [dostęp: 20.01.2020].

United Nations Development Programme. (2018). Human Development Indices and Indicators. 2018 Statistical Update. Pobrane z: http://hdr.undp.org/sites/default/ files/2018_summary_human_development_statistical_update_en.pdf [dostęp: 10.04.2020].

Uryga, Z. (1996). Godziny polskiego. Z zagadnień ksztatcenia literackiego. WarszawaKraków: PWN.

Watts, C. (1983). 'A Bloody Racist': About Achebe's View of Conradd. The Yearbook of English Studies, no. 13, 196-209, DOI: https://doi.org/10.2307/3508121.

Wileczek, A., Jaros, I. (2014). Cyfrowe słowa... Nowoczesne aplikacje multimedialne w kształceniu polonistycznym (etap wczesnoszkolny). W: K. Biedrzycki, A. Kania, E. Strawa-Kęsek (red.), Polonistyka dziś - kształcenie dla jutra (T. 2; s. 123-133). Kraków: TAiWPN Universitas.

Wóycicki, K.D. (1920-1921). Rozbiór literacki w szkole. Podręcznik dla nauczycieli. Warszawa.

Wróblewski, M. (2014). Człowiek w przestrzeniach szkoły. Studium antropologiczne. Toruń: Wydawnictwo Naukowe Uniwersytetu Mikołaja Kopernika.

Yordanova, D. (2012). Multimedia in the Bulgarian language and literature lessons in the first through the fourth grade. Revista Academiei Fortelor Terestre, no. 4, 408-412.

Załuski, Z. (1962). Siedem polskich grzechów głównych. Warszawa: Czytelnik.

Zasacka, Z. (2015). Antynomie szkolnych i pozaszkolnych lektur. Polonistyka. Innowacje, nr 2, 35-50, DOI: https://doi.org/10.14746/pi.2015.1.2.3.

\section{Akty prawne}

Rozporządzenie Ministra Edukacji Narodowej z dnia 21 maja 2001 roku w sprawie ramowych planów nauczania w szkołach publicznych (Dz.U. 2001, nr 61, poz. 626).

Rozporządzenie Ministra Edukacji Narodowej i Sportu z dnia 26 lutego 2002 roku w sprawie podstawy programowej wychowania przedszkolnego oraz kształcenia ogólnego w poszczególnych typach szkół (Dz.U. 2002, nr 51, poz. 458).

Rozporządzenie Ministra Edukacji Narodowej z dnia 30 listopada 2006 roku zmieniające rozporządzenie w sprawie podstawy programowej wychowania przedszkolnego oraz kształcenia ogólnego w poszczególnych typach szkół (Dz.U. 2006, nr 228, poz. 1669).

Rozporządzenie Ministra Edukacji Narodowej z dnia 3 lipca 2007 roku zmieniające rozporządzenie w sprawie podstawy programowej wychowania przedszkolnego oraz kształcenia ogólnego w poszczególnych typach szkół (Dz.U. 2007, nr 123, poz. 853).

Rozporządzenie Rady Ministrów z dnia 24 lipca 2007 roku uchylające rozporządzenie Ministra Edukacji Narodowej zmieniające rozporządzenie w sprawie podstawy programowej wychowania przedszkolnego oraz kształcenia ogólnego w poszczególnych typach szkół (Dz.U. 2007, nr 136, poz. 961).

Rozporządzenie Ministra Edukacji Narodowej z dnia 23 sierpnia 2007 roku zmieniające rozporządzenie w sprawie podstawy programowej wychowania przedszkolnego oraz kształcenia ogólnego w poszczególnych typach szkół (Dz.U. 2007, nr 157, poz. 1100). 
Pobrane z czasopisma Annales N - Educatio Nova http://educatio.annales.umcs.pl Data: 26/04/2023 01:42:58

68 Anna Ślósarz

Rozporządzenie Ministra Edukacji Narodowej z dnia 29 sierpnia 2008 roku zmieniające rozporządzenie w sprawie podstawy programowej wychowania przedszkolnego oraz kształcenia ogólnego w poszczególnych typach szkół (Dz.U. 2008, nr 159, poz. 992).

\section{Strony internetowe}

FindFace. https://findface.pro [dostęp: 20.11.2020].

Klasyka Literatury. Ostatni dzwonek. https://ostatnidzwonek.pl [dostęp: 20.11.2020]. Kulturalna Polska. https://klp.pl [dostęp: 20.01.2020].

Ściąga. https://sciaga.pl [dostep: 20.11.2020]

VEO. www.veo-group.com [dostęp: 20.11.2020]. 